\title{
Project Life Cycle Risk of Public-Private Partnership (PPP) Projects for Construction Sustainability
}

\author{
F. A. Mohd-Rahim*, M. S. Abd-Rahim, N. Zainon, L. S. Chuing, Z. Abd-Samad. \\ Centre for Building, Construction \& Tropical Architecture, Faculty of Built Environment, \\ University of Malaya, 50603 Kuala Lumpur. \\ *azli@um.edu.my
}

Received: 2 May 2017 Final Version Received: 21 May 2018

\begin{abstract}
One of the principles of PPP projects is value for money in maintaining the constructionsustainability of a project. Thus, driven by this necessity, for the purpose to seek a solution in minimizing both the total management costs to the public and private sectors firms, the risks identified in PPP projects must be allocated to the party who is able to manage it effectively. Evidence from projects worldwide shows that risks are not managed properly, and little attention has been committed in the Malaysian research community to systematically identify and manage the risk in Malaysian PPP projects. This paper reviewing the concept of Public-Private Partnership (PPP) in Malaysian construction industry by identifying the critical risks factors in PPP projects and explores the actions taken by the private party in managing these risks. A mixed methodology of quantitative and qualitative approaches was used to identify the allocation, probability and impact of the risk factors and determine what risk response measures are used to deal with the critical risks. The outcome from this study revealed that there are 23 risk factors allocated to private parties determined as critical risk factors. This study also proposed 79 risk responses taken by private parties to manage the critical risks. Private parties have to adopt the relevant skills and knowledge in risk management to ensure the projects were successfully gives a value to the public without compromising their profit and improving the sustainability of the construction project.
\end{abstract}

Keywords: Risk management, Public Private Partnership, construction projects, life cycle, sustainability

\section{INTRODUCTION}

The expansion growth of Malaysia construction industry has been catalyzed by the Government's major capital expenditure on construction projects especially in the private sector projects. From 2011 to 2014, a total of 29,435 construction projects valued at RM470 billion (EPU, 2015) were awarded to the construction industry from the year 2011 to 2014. These were largely private sector projects totalling RM387 billion or $82 \%$ of total value, with the remaining RM83 billion from public sector projects. The key factors of the major capital expenditure are the Government's Economic Transformation Programme (ETP) and Public-Private Partnership (PPP) projects, which have had a domino effect across the Malaysia construction industry in recent years.

The Government through the Malaysia Plans and Economic Transformation Programme (ETP) has increased total infrastructure construction demand from RM93.3 billion in 2007 to RM116.9 billion in 2013, an increase of more than 25\% (CIDB, 2014). Accordingly, the government has announced various mega development projects with the aim of bringing long-lasting economic growth to the country. These great strides have been contributing to the country's economy and resulted in other implications especially to both social and environmental aspects of the country. The demand pertinent to the construction industry has been forecasted to gradually increase over the years due to the Government's stimulus package to enhance development projects under the Public-Private Partnership (PPP) Programme. This has led to an ever-increasing share of the total demand of the private sectors.

One of the key features in Public-Private Partnership (PPP) is to optimize the sharing of risk through the allocation of risk to the party who is the best able to manage (OECD, 2007; Faizul et al, 2017). According to Guideline to Victoria PPP (2000), the core principle for Public-Private Partnership's (PPP) is value for money. The private sector companies' goals are; to gain a return on their investment to generate adequate future cash flows in order to cover finance charges and initial capital costs. 
Therefore, they can provide enough profit to invest in future projects as well as to pay shareholder dividends. In contrast, the public sector aims at ensuring cost-effective, timeeffective, and high-quality level of services to the community than if the public sector had retained responsibility $(\mathrm{Ng}, 2005)$.

Risk in Public-Private Partnership (PPP) projects has its roots in the incomplete contracting nature and the complexity of arrangements, which have led to increased risk exposure for all the parties, involved (Boadua, 2012). Truth to be told, the risks cannot be eliminated but the risks can be managed (Ng, 2005). Accordingly, evaluation of the potential risks throughout the whole project life in order to have a proper risk management framework is of utmost important for the public client and private bidders (Chan, 2011). This is more so for PPP implementation, due to the long concession period, large project scale, complexity and social sensitivity usually associated with PPP projects (Lewis, 2000).

This paper, in reviewing the concept PublicPrivate Partnership (PPP), identifies the critical risks in PPP projects and explores the actions taken by the private party in managing these risks. A mixed methodology of quantitative and qualitative approaches was used to identify the allocation, probability and impact of the risk factors and determine the risk response measures used to deal with the critical risks.

\section{PUBLIC-PRIVATE PARTNERSHIP (PPP )}

Public-Private Partnership (PPP) Programme has its roots in the mid-1980s known as the jointventure arrangements between local government and developers. PPP and often its interpretations are frequently confused with privatization, however, in Malaysia its boundaries and frontiers are quite distinguishable (Faizul et al, 2017). PPP can be highlighted as a derivative of privatization (Pongsiri, 2002), a concept that emerged under the administration of $4^{\text {th }}$ Prime Minister, Tun Mahathir Mohamad. Previously, PPP in Malaysia was subjected to a traditional perspective, which has been perceived to be a derivative of the privatization policy; however, its current interpretation refers to private sector involvement in public infrastructure development. PPP was emerged to enforce the relationship between both public and private sectors in order to deliver the public projects.

The Malaysia Government is very determined to make PPP Programme work, which can be gauged by looking at the efforts currently being planned. In the Ninth Malaysia Plan (20062010), about 22 projects with an estimated value of RM12 billion were undertaken via privatization and PPP. Bank Pembangunan Malaysia Berhad (2011) reported as, during the $10^{\text {th }}$ Malaysia Plan, 52 high impact projects worth RM63 billion was implemented via the PPP approaches. Some of the projects include seven toll highways, five Universiti Teknologi MARA (UiTM) branch campuses, the Integrated Transport Terminal in Gombak, and the redevelopment of Angkasapuri Complex in Kuala Lumpur as a Media City.

As articulated by United Nations Economic and Social Commission for Asia and the Pacific (2011), as cited in Karim (2011), PPP models can be categorized as five, namely; private ownership of assets and private finance initiative type, supply and management of contract, turnkey, lease, and concessions (Table 1). The mentioned models vary in terms of ownership of capital assets, responsibility for investment, assumption of risk and duration of contract (Karim, 2011).

Table 1: Classification of Public-Private Partnership (PPP) models (Karim, 2011)

\begin{tabular}{|c|c|c|c|c|c|}
\hline Broad category & Main variants & $\begin{array}{l}\text { Ownership of } \\
\text { capital assets }\end{array}$ & $\begin{array}{l}\text { Responsibility } \\
\text { of investment }\end{array}$ & $\begin{array}{l}\text { Assumption of } \\
\text { risk }\end{array}$ & $\begin{array}{l}\text { Duration of } \\
\text { contract (years) }\end{array}$ \\
\hline \multirow{3}{*}{$\begin{array}{l}\text { Supply and } \\
\text { management } \\
\text { of contract }\end{array}$} & outsourcing & public & public & public & $1-3$ \\
\hline & maintenance & public & public/private & public/private & $3-5$ \\
\hline & $\begin{array}{l}\text { Operational } \\
\text { operation }\end{array}$ & public & public & public & $3-5$ \\
\hline Turnkey & & public & public & public/private & $1-3$ \\
\hline \multirow[t]{3}{*}{ Lease } & Lease & public & public & public/private & $5-20$ \\
\hline & Lease (BLT) & public & public & public/private & $5-20$ \\
\hline & Franchise & public/private & public/private & public/private & $3-10$ \\
\hline Concessions & $\begin{array}{l}\text { BOT, BTO, } \\
\text { BOOT, BROT }\end{array}$ & public/private & public/private & public/private & $15-30$ \\
\hline
\end{tabular}




\begin{tabular}{|c|c|c|c|c|c|}
\hline \multirow{3}{*}{$\begin{array}{l}\text { Private } \\
\text { ownership of } \\
\text { assets and PFI }\end{array}$} & $\mathrm{BOO} / \mathrm{DBFO}$ & private & private & private & Indefinite \\
\hline & $\begin{array}{l}\text { Private } \\
\text { Finance } \\
\text { Initiative }\end{array}$ & public/Private & private & public/private & $10-20$ \\
\hline & Divesture & private & private & private & Indefinite \\
\hline
\end{tabular}

The traditional projects are literally not involved in sharing with private sector. Therefore, in traditional projects, the public sector will undertake the risks compared to the (PPP) projects. However, in PPP arrangements, the risk shares between both parties and the private sector undertake a certain portion of the risks encompassing construction, design, maintenance and operation as well. Simultaneously, the public sector handles risks, which are difficult to control by the private sector alone such as environment and government approval risks.

Another source of difference can be seen as the financial package of the project. The traditional projects are financed by the public sector, however, in a PPP project; the private consortium will have some equity in the asset being delivered (Cheung, 2009). The private financial investment has gained its important position as the vital element of PPP projects in various countries in order to pave the way against government's financial burden; thus, many people have an inclination to equate PPP to Private Finance Initiative (PFI). According to World Bank (2012), PPP is not a privatization because accountability of delivery of the public service is constrained by the public sector. On the other hand, in privatization, the private sector is responsible for accountability. In addition, since there is no transfer of ownership in PPP, then the public sector remains accountable to the assets.

The application of the life-cycle approach is the element in the PPP project that binds three important elements of the PPP model (outputbased specifications, functional requirements, and the risk transfer) together with the mean to increase value for money (Eldrup \& Schütze, 2013). Life-cycle costing (LCC), life-cycle economics (LCE) and environmental life-cycle economic (environmental LCE) are among the three types of life-cycle approaches existing in PPP projects (Eldrup \& Schütze, 2013).

According to Eldrup \& Schütze (2013), the life-cycle approach is traceable within both phases of design and construction. When the public procurer and a private partner have signed a contract, the partner is still encouraged to take proactive actions toward optimizing the economics of their investments. Indeed, this is because the long-term nature of the contract reflects both operation and construction phases. Another robust reason that why there is a need to deploy life-cycle approach during the contract is; the contract would implement contract clauses that obligate the public procurer and the consortium to consider improvements with a positive net present value seen over a period that goes beyond the end of the contract.

\section{RISK MANAGEMENT IN PPP PROJECTS}

In PPP projects, the risks that should be assumed in advance are expected to be numerous because it composed a number of parallel organizations such as private entity, the public sector, and financial institutions, and also because the project period is lengthy. Hence, to smoothly evaluate the risks and their allocations, it is valuable to analyze the risk from various perspectives.

As proposed by Bing Li et al. (2005) risks in PPP projects are clustered as three clusters Macro (i.e., risk that sourced exogenously or external), Meso (i.e., risk that sourced endogenously where the event and its consequences happening within the system boundaries of the project) and Micro risks (i.e., risk that sourced endogenously and found in the stakeholder relationships formed in the procurement process, more party related rather than project related) (Figure 1).

Figure 2 shows the proposed risk breakdown structure for Malaysian construction projects which consists of total 59 numbers of risk factors, and serves as the fundamental for the study in this research. These 59 risks were collected from literature such as journal papers and books worldwide as well as those especially focused on the Malaysian industry (Flanagan \& Norman, 1997; Ismail et al., 2013; Mahamid, 2013). Macro risks were divided into 5 categories or sub-groups which have 27 risk factors. Meso risks have 6 categories or 
sub-groups which consist of 24 risk factors, while micro risks have 2 categories or subgroups which have total 8 risk factors.

$\mathrm{Ng}$ and Loosemore (2007) stated that it is impossible for a construction project to gain zero risk because risk inherently occurred in all phases of construction projects According to Zaini et al. (2010), a systematic risk management is required in order to cut down on the complexity of risk in construction. Flanagan \& Norman (1997) defined risk management as "a system which aims to identify and quantify all risks to which the business or project is exposed so that a conscious decision can be taken on how to manage the risks". Risk management means effort for reducing the probability that risk exists to the greatest extent possible and effort to minimize the consequences and their impact as much as possible if the risk became apparent. One of the fundamental approaches in risk management of Public-Private Partnership (PPP) projects is the risk allocation between parties involves (OECD, 2007).

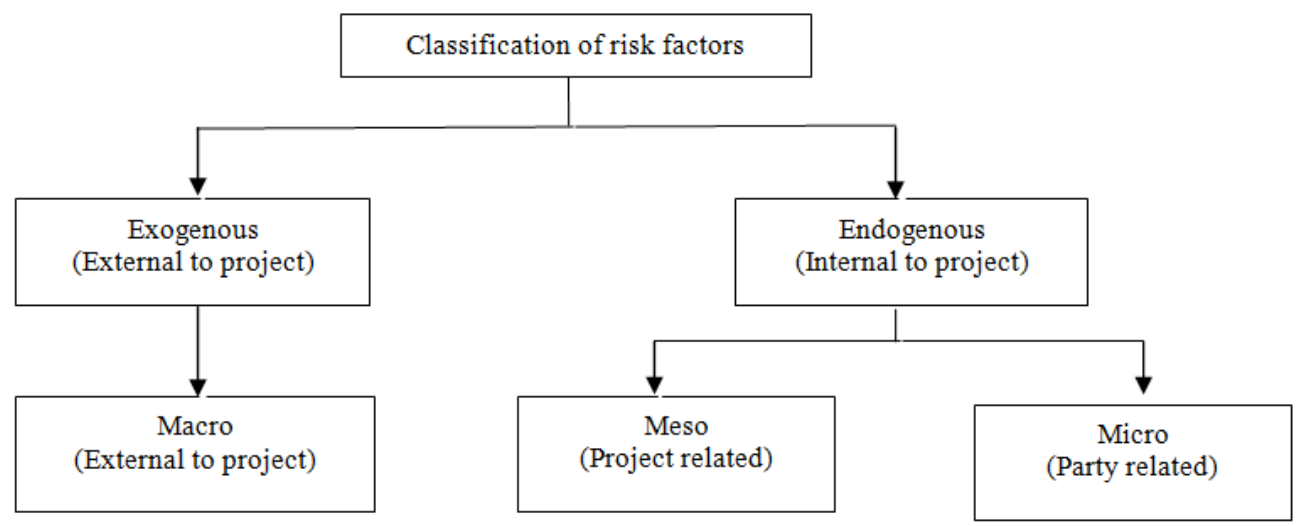

Figure 1: Classification of risk factors (Adapted from Bing Li et al., 2005)

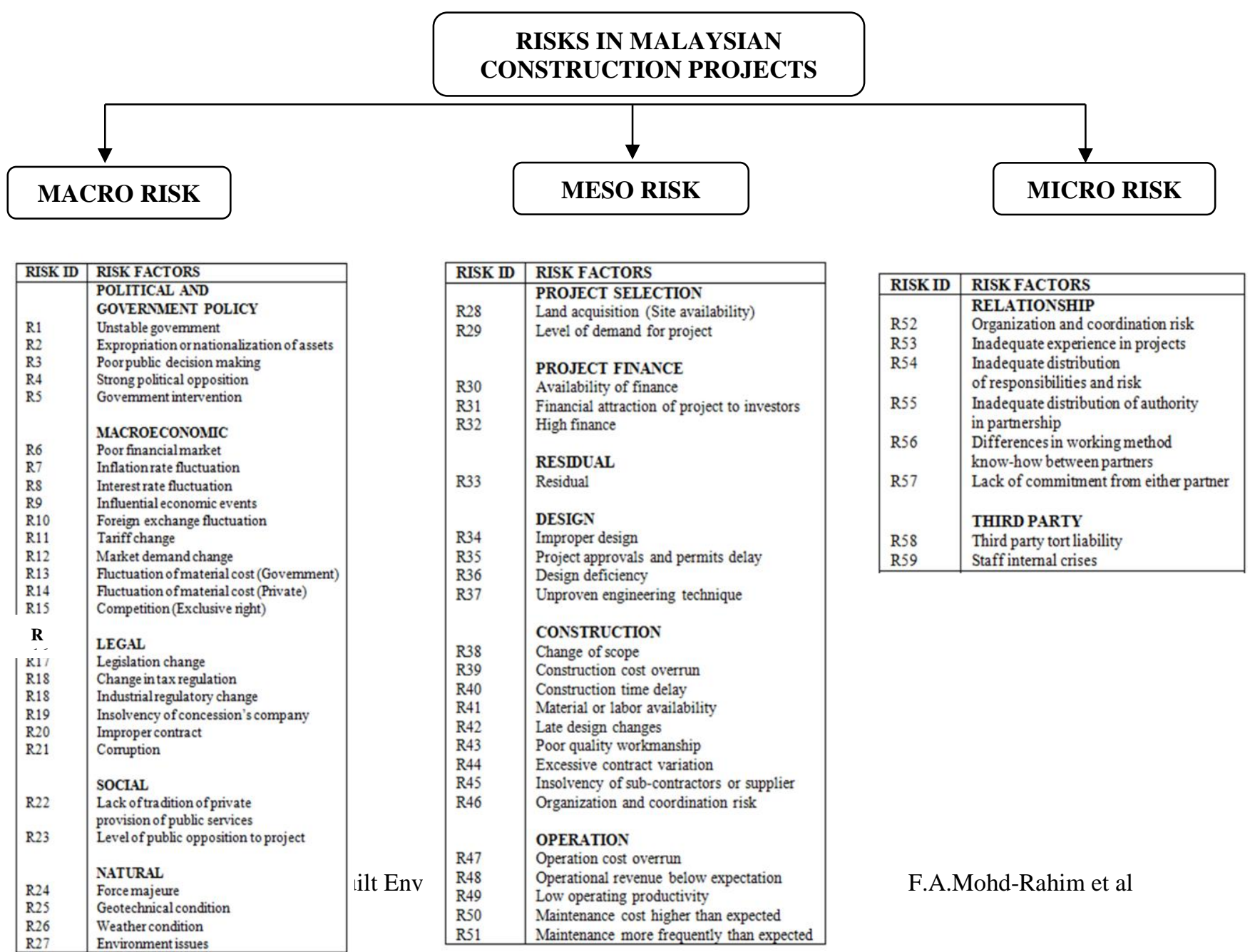




\section{RISK ALLOCATION IN PPP PROJECTS}

From the perspectives of risk allocation, there are several challenges that need to be considered in the implementation of PPP projects. The most wellknown phrase when considering risk allocation is "the risk should be allocated to the party who is best able to manage it" (Merna and Njiru, 2002). Risk allocation is a primary measure of assignment between the public and private sector and serves to help the both sectors achieving a balanced distribution of responsibilities (Bing $\mathrm{Li}$ et al. 2005).

The main driver of PPP projects is value for money thus based on this requirement, the risks identified in construction projects must be allocated to the best party that can manage it effectively $(\mathrm{Ng}$, 2005). PPP also serves to search for a solution in minimizing the total management costs, which have to be borne by all parties involved in the project (Chan, 2011). The allocation of risk in PPP projects can be conducted based on three main groups which are; risk that should be allocated only to public, risk that should be allocated solely to private and risk should be shared between public and private party (Figure 3) (Bing Li et al., 2005).

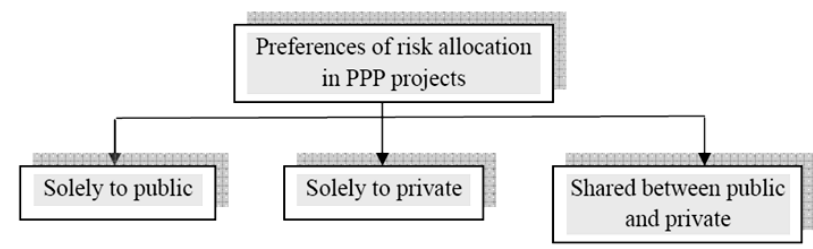

Figure 3: Preference of risk allocation (Bing Li et al. 2005)

It was highlighted that risk allocation is one of the advantages of PPP because it plays a role as the enabler, which leads to encouraging sharing risks between both public and private sector Shen et al. (2006). Therefore, risk allocation has manifested itself as a vital prerequisite to the successful development of PPP projects emphasizing the correlation with contract negotiation (Wang and Dai, 2009). The decision about how risk might be allocated between both sectors will be carried out considering the degree of value for money, which is created for the public procurer from the specific PPP projects when shifting the risk allocation (Table 2).

Table 2: Risk allocation arrangement for Public-Private Partnership (PPP) projects

\begin{tabular}{|c|c|c|}
\hline $\begin{array}{l}\text { Party affected } \\
\text { by and/ or }\end{array}$ & Public sector & Private sector \\
\hline Types of risk & $\begin{array}{l}\text { Closure Risk: The inability } \\
\text { of the bidding party to } \\
\text { reach financial closure. } \\
\text { Land risk: expropriation } \\
\text { and eminent domain issues, } \\
\text { difficulties acquiring land. } \\
\text { Bankruptcy risk: Private } \\
\text { company declares } \\
\text { bankruptcy while working } \\
\text { on a contract. }\end{array}$ & $\begin{array}{l}\text { Design, construction, and maintenance risk: includes day- } \\
\text { to-day operational and management risks, delays in } \\
\text { acquiring necessary permits, problems with } \\
\text { subcontractors, completion risk, and cost and schedule } \\
\text { overruns. } \\
\text { Demand/revenue risk: includes unexpectedly high or low } \\
\text { demand compared to initial market assessments. } \\
\text { Political risk: changes in government, changes in public } \\
\text { policy, corruption and favoritism, lack of sanctity of } \\
\text { contract, and arbitration difficulties. } \\
\text { Currency risk: unexpected severe depreciation or } \\
\text { appreciation of currency that affects the service provider's } \\
\text { ability to pay investors. }\end{array}$ \\
\hline
\end{tabular}

\section{METHODOLOGY}

This study employs an explanatory mixed methods design. A questionnaire survey is used to get a quantitative data. The risk factors from the proposed risk breakdown structure (Figure 2) provide the basis to construct the questionnaire. Once the risk factors listed in the questionnaire were ranked by respondents, the semi-structured interviews with open-ended questions were 
conducted to investigate what risk response taken by the private firms to manage the high level or critical risk faced. Due to the limitation of space allowed for this journal publication, the detail descriptive data of the study was not provided.

The survey feedback encompasses three groups of data which are the risk allocation preferences, the risks probability (also known as severity or likelihood) and its impact (also known as consequence or severity) if the risk occurs. After risks are identified, their characteristics need to be assessed so that it is determined whether the risk event is worth further analysis. In this study, the risk is measured using two parameters - risk probability and risk impact, as quoted by Ahmed (2007) in his research, where risk probability indicates a possibility of a risk event happening (Table 3), while risk footprint indicates an outcome generated from the risk event (Table 4). Risk magnitude is the product of risk probability and impact and can be calculated through Eq. (1);

$$
\text { Risk Magnitude = Probability } \mathrm{x} \text { Impact }
$$

Once risk magnitude for each risk factor was calculated, the risk zone for each identified factors can be determined by using risk matrix zone boxes with magnitude scale (Cervone, 2006)

Table 3: Scale used to identify the probability of risk occurrence

\begin{tabular}{lll}
\hline Probability of occurrence & Description & Scale (Point) \\
\hline Very High (VH) probability & Likely occurrence with $80-100 \%$ chances & 5 \\
High (H) probability & Likely occurrence with $60-80 \%$ chances & 4 \\
Moderate (M) probability & Likely occurrence with $40-60 \%$ chances & 3 \\
Low (L) probability & Likely occurrence with 20-40\% chances & 2 \\
Very Low (VL) probability & Likely occurrence with below 20\% chances & 1 \\
\hline
\end{tabular}

Source: Cervone, 2006

Table 4: Scale used to identify impact of risk

\begin{tabular}{llc}
\hline $\begin{array}{l}\text { Impact of } \\
\text { risk }\end{array}$ & \multicolumn{1}{c}{ Description } & $\begin{array}{c}\text { Scale } \\
\text { (Point) }\end{array}$ \\
\hline $\begin{array}{l}\text { Critical risk } \\
\text { Serious risk }\end{array}$ & $\begin{array}{l}\text { Would cause project failure } \\
\text { Would cause major cost or schedule increase and secondary requirements in } \\
\text { project may not be achieved }\end{array}$ & 5 \\
Moderate & $\begin{array}{l}\text { Would cause moderate cost/schedule increases, important requirements } \\
\text { risk }\end{array}$ & 3 \\
$\begin{array}{l}\text { Minor risk } \\
\begin{array}{l}\text { Negligible } \\
\text { risk }\end{array}\end{array}$ & $\begin{array}{l}\text { Would cause only small cost/schedule increase } \\
\text { Would have no substantive effect on cost or schedule }\end{array}$ & 2 \\
\hline
\end{tabular}

Table 5: Risk matrix zone boxes with magnitude scale

\begin{tabular}{|l|c|c|c|c|c|}
\hline Impact & $\begin{array}{c}\text { Negligible } \\
\text { risk } \\
\text { Probability }\end{array}$ & $\begin{array}{c}\text { Minor } \\
\text { risk } \\
-2\end{array}$ & $\begin{array}{c}\text { Moderate } \\
\text { risk } \\
-3\end{array}$ & $\begin{array}{c}\text { Serious } \\
\text { risk } \\
-4\end{array}$ & $\begin{array}{c}\text { Critical } \\
\text { risk } \\
-5\end{array}$ \\
\hline Very Low (VL) -1 & $\mathbf{1}$ & $\mathbf{2}$ & $\mathbf{3}$ & $\mathbf{4}$ & $\mathbf{5}$ \\
\hline Low (L) -2 & $\mathbf{2}$ & $\mathbf{4}$ & $\mathbf{6}$ & $\mathbf{8}$ & $\mathbf{1 0}$ \\
\hline Moderate (M) -3 & $\mathbf{3}$ & $\mathbf{6}$ & $\mathbf{9}$ & $\mathbf{1 2}$ & $\mathbf{1 5}$ \\
\hline High (H) - 4 & $\mathbf{4}$ & $\mathbf{8}$ & $\mathbf{1 2}$ & $\mathbf{1 6}$ & $\mathbf{2 0}$ \\
\hline Very High (VH) -5 & $\mathbf{5}$ & $\mathbf{1 0}$ & $\mathbf{1 5}$ & $\mathbf{2 0}$ & $\mathbf{2 5}$ \\
\hline
\end{tabular}

Source: Cervone, 2006

In this study, the data for risk probability and impact collected from the survey was analyzed using mean value. The rationale of such method is explained by Cervone (2006). Mean value is the integral of a continuous function of one or more variables over a given range divided by the 
measure of the range. The formulae to find the mean value for each risk factor probability and impact can be calculated through Eq. (2);

Magnitude of risk $=($ Amount of selected probability/n) x (Amount of selected risk impact/n) (2)

Where; $\mathrm{n}=$ Total number of respondents

Amount of selected risk probability $=($ Scale $1 \mathrm{x}$ no. of respondent $)+($ Scale $2 \times$ no. of respondent $)$ $+\ldots \ldots \ldots \ldots+($ Scale $5 \mathrm{x}$ no. of respondent $)$

Amount of selected risk impact $=($ Scale $1 \mathrm{x}$ no. of respondent $)+($ Scale $2 \times$ no. of respondent $)+$ ......... + (Scale $5 \mathrm{x}$ Amount of respondent)

In addition to the questionnaire survey for collecting data, semi-structured interviews with open-ended questions were conducted to investigate what risk response taken by the private firms to manage the high level or critical risk faced. The open-ended questions provide an opportunity for respondents to express their opinions on an issue more clearly rather than be restrained by pre-determined questions.

Four in-depth semi-structured interviewed were performed with the selected experts from various private sector firms such as developer, consultant and contractor who is familiar and have experienced involved in the risk management activities of PPP projects. Before conducting the interview session with the respondents, researcher had a phone conversation with selected potential respondents to analyze their level of experience in managing risks and to get their permission to be interviewed. The interviewees of the private party agreed to have the face-to-face interviews with tape-recorded and hand-written notes also taken. The period of time allotted for each interview was between one and a half hours to two hours. In this study, the respondents were code as A, B, C and D. The idea of having the in-depth interviews by four experienced respondents was to highlight the importance of the critical risk factors, in relevance to their years of experience. This supporting interview resulted consistently in agreement on the common variables by interviewee $\mathrm{A}$ and $\mathrm{B}$, and the common risk factors by interviewee $\mathrm{C}$ and $\mathrm{D}$. This may be due to the fact that the years of experience of $\mathrm{A}$ and $\mathrm{B}$, which were more than 15 years, whereas for interviewee $\mathrm{C}$ and $\mathrm{D}$ were only 10 years. The level of management also plays a role in the differences of the opinions.

Table 6: List of respondents for semi-structured interview

\begin{tabular}{|c|c|c|c|c|c|c|}
\hline Code & Designation & $\begin{array}{l}\text { Services provided in } \\
\text { PPP projects }\end{array}$ & $\begin{array}{l}\text { Experiences } \\
\text { in industry }\end{array}$ & \multicolumn{3}{|c|}{ Types of PPP projects } \\
\hline $\mathrm{A}$ & $\begin{array}{ll}\text { Head } & \text { of } \\
\text { Department }\end{array}$ & $\begin{array}{l}\text { Project Management } \\
\text { Consultant \& SPV }\end{array}$ & $\begin{array}{l}\text { More than } \\
15 \text { years }\end{array}$ & $\begin{array}{l}\text { Government } \\
\text { apartment }\end{array}$ & building, & Government \\
\hline $\mathrm{B}$ & General Manager & Developer & $\begin{array}{l}\text { More than } \\
15 \text { years }\end{array}$ & $\begin{array}{l}\text { Government } \\
\text { apartment }\end{array}$ & building, & Government \\
\hline $\mathrm{C}$ & $\begin{array}{l}\text { Construction } \\
\text { Manager }\end{array}$ & Contractor & 10 years & $\begin{array}{l}\text { Government } \\
\text { apartment }\end{array}$ & building, & Government \\
\hline $\mathrm{D}$ & $\begin{array}{l}\text { Associate } \\
\text { Director }\end{array}$ & Consultant & 10 years & $\begin{array}{l}\text { Government } \\
\text { apartment }\end{array}$ & building, & Government \\
\hline
\end{tabular}

\section{RESULT AND DISCUSSIONS}

Risk management has a responsibility to help project stakeholders in identifying project risks and effectively manage them. The aim of this study is not only to produce a list of risks in construction projects but also to determine the critical risk factors that can substantially influence the implementation of PPP projects. From the questionnaire survey analysis, the feedback concerning the preferred risk allocation of Malaysian PPP project was presented in structure as depicted in Figure 5. The principle of analysis is according to the level of majority (highest percentage) opinion.

Out of the 59 identified risk factors, 8 risks are solely assigned to the public sector and 40 risk factors are preferred to be assigned solely to the private party (Figure 5). It can be seen that that almost all the risks assigned to the public sector have the same characteristic where they are pertinent to government or government officer and their actions. The private sector undertakes the most of responsibility for meso level risks which includes risk in the sub groups; project selection, project finance, design, construction and operation. 
Most of these risks are categorized within the particular project risk category. There are 11 risks shared by both parties which are legislation change, improper contract, level of public opposition to project, force majeure, project approvals and permits delay, excessive contract variation, inadequate experience in PPP projects, inadequate distribution of responsibilities and risks, inadequate distribution of authority in partnership, lack of commitment from either partner and staff internal crises. All abovementioned risks have same features in common that both public and private sectors may not be able to cope with it individually. Therefore, it can be asserted that a shared mechanism is a best practice.

From the questionnaire survey analysis, private sectors bear much of the proposed risk factors, with only 8 risk factors were not allocated to the private sector, signifying that the respondents did not encounter them. Hence, the 8 risk factors were eliminated from the earlier proposed risk breakdown structure. Figure 6 shows the risk magnitude breakdown structure of the risk factors which were allocated to private sector undertaking PPP projects in Malaysia. 23 of risk factors (out of 51 risk factors) are categorized as critical level risks. 16 of the critical risks are from meso categories, 5 from macro categories and 2 of risk factors are from micro categories. Risk factors that fall under this group are critically importance in PPP projects and a close attention should be paid to them. Failures to deal with these risks are the main cause for exceeding budget, falling behind schedules and missing performance targets in many PPP projects.

\section{CONCLUSION}

The findings revealed that there are eight out of fifty-nine identified risk factors to be solely assigned to the public which are volatile government, expropriation or nationalization of assets, poor public decision-making process, strong political opposition, government intervention, fluctuation of material cost (by government), land acquisition (site availability) and change of project scope. While, forty out of fifty-one identified risk factors are intended to be solely assigned to private party, where majority of the risk factors are at meso categories risks which include risk in the sub groups namely project selection, project finance, design, construction and operation. Most of these risks are clustered within the specific project risk cluster. There are eleven identified risk factors to be shared by both parties where all the risks, public and private parties may not be capable of coping with it solely, hence, a shared mechanism would appear to be the best solution.

Taking a step further, the risk factors allocated to the private party (either solely or shared) based on risk magnitude level were determined. There are eight out of fifty-one risk factors classified as lowlevel risk, twenty risk factors were classified as moderate level, and twenty-three out of fifty-one risk factors were classified as critical risks. Seventy percent of the critical level risks are at meso categories which mean the sources of risk comes from internal project environment, and most of them arise from the construction and operational activities. Although two critical risks arise at micro categories, organization and coordination risk magnitude was score highest and was ranked first in the risk magnitude ranking order.

The risk responses taken by private party through the interviews could be extracted from Table 7, which depicted a few risk response methods for various critical risks encountered. Through the interviews, the responses practiced can be exercised in the project were, in no specific order:

- Prevention and protection throughout the procurement selection process.

- Awareness and planning during the delivery phase

- Recovery and impact mitigation plan

- Clear project scope

- Team to coordinate the work

- Clear line of communication and reporting

- Team building.

Besides adhering to this list of risk responses, the private parties have to constantly monitor the project's risks from all level including the risks at low and moderate level, and finding strategies to mitigate them based on their organization culture, capability and the available resources.

\section{ACKNOWLEDGEMENTS}

This research is supported by the project grant, RP007B-13SUS 'Whole life cycle for sustainable construction', and project grant BK002-2017, 'Modelling Drivers and Barriers to Adopting Risk Management Practices in Malaysian Small Construction Projects'. 


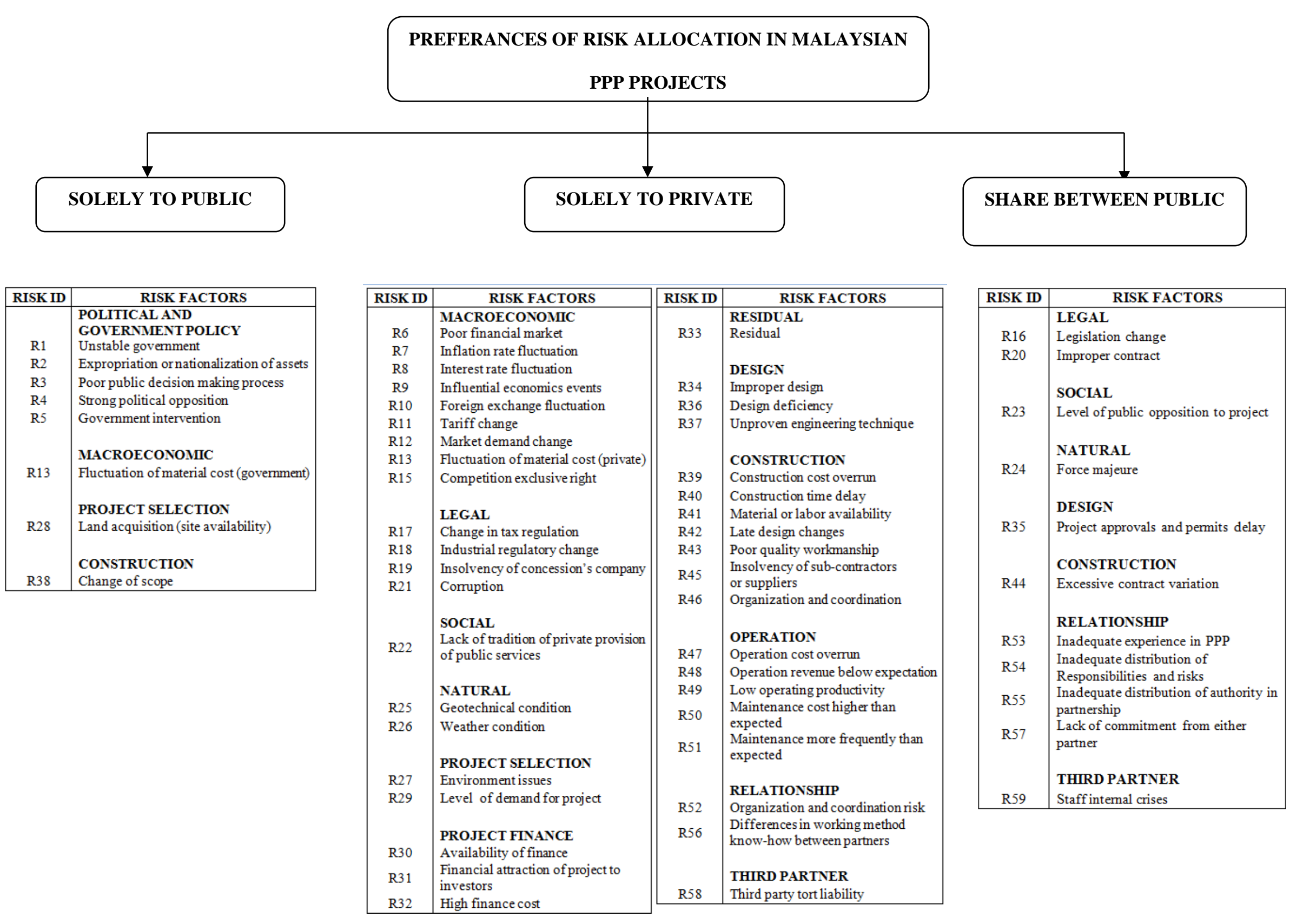

Figure 5: Preferences of risks allocation in Malaysian PPP projects 


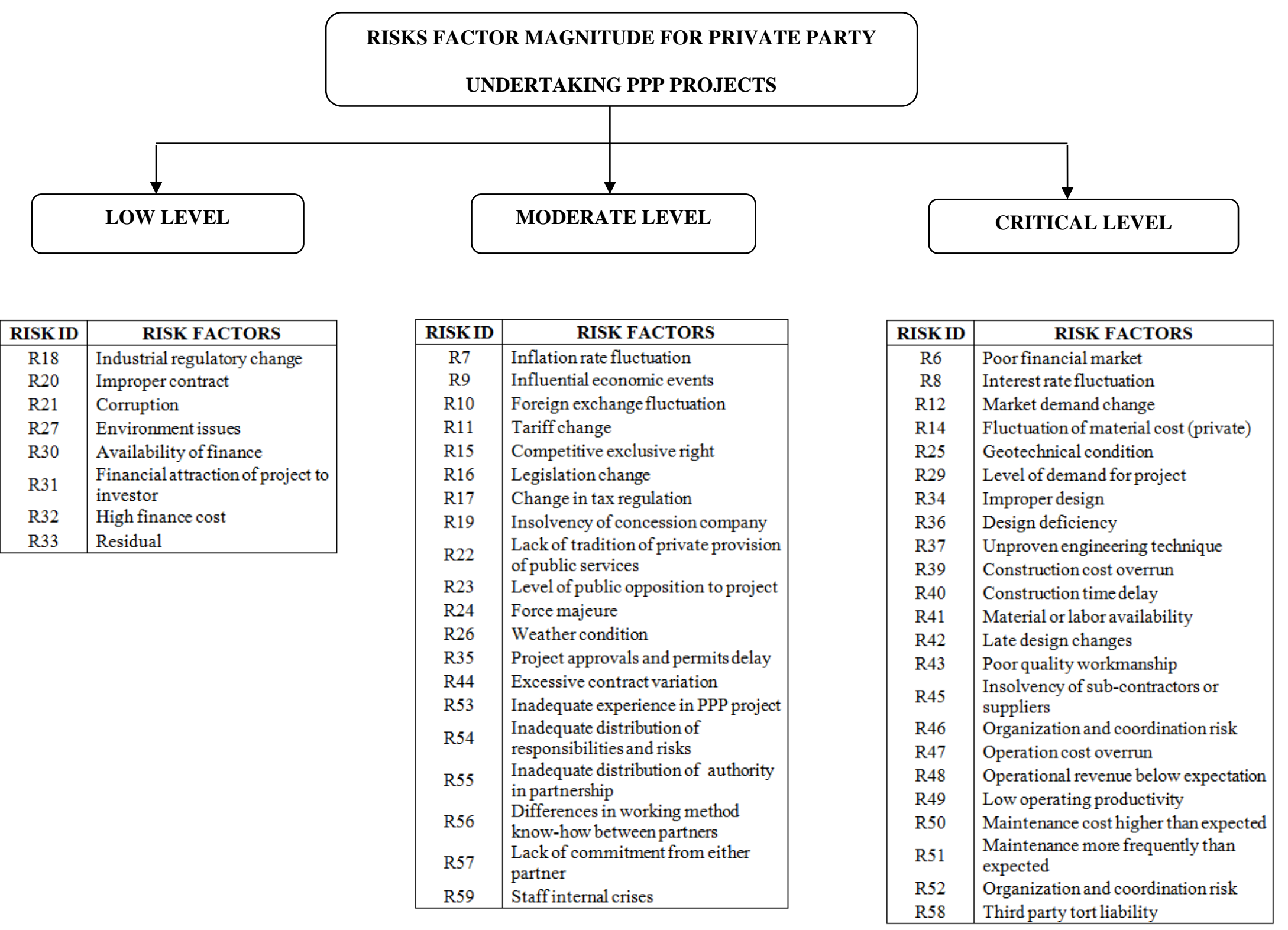

Figure 6: Risk factors magnitude breakdown structure for private party undertaking PPP projects in Malaysia (based on its characteristic) 
Table 7: Summary of risk responses from the interview for the critical risk factors

\begin{tabular}{|c|c|c|c|c|c|}
\hline $\begin{array}{l}\text { Risk } \\
\text { rank }\end{array}$ & $\begin{array}{l}\text { Risk } \\
\text { factor } \\
\text { code }\end{array}$ & Risk factor & $\begin{array}{c}\text { Risk } \\
\text { Response } \\
\text { (RR) code }\end{array}$ & Summary of risk response & Respondents \\
\hline \multirow[t]{4}{*}{1} & R52 & Organization and coordination risk & RR69 & Set clear and realistic policies & $\mathrm{A}$ \\
\hline & & (Micro level-relationship) & RR70 & Public to has dedicated team institutions and competence officers. & A \\
\hline & & & RR72 & Public to assist private party mitigate their allocated risk. & A \\
\hline & & & RR73 & Transparent procedures. & A \\
\hline \multirow[t]{2}{*}{2} & R40 & Construction time delay & RR17 & Sufficient resource & $\mathrm{A}, \mathrm{B}, \mathrm{C}$ \\
\hline & & & RR18 & Well organize resources & $\mathrm{A}, \mathrm{B}, \mathrm{C}$ \\
\hline \multirow[t]{2}{*}{3} & R39 & Construction cost overrun & RR15 & Conduct detail study & $\mathrm{B}, \mathrm{C}$ \\
\hline & & & RR16 & Practice good project management & $\mathrm{A}, \mathrm{B}, \mathrm{C}$ \\
\hline \multirow[t]{3}{*}{4} & R34 & Improper design & RR21 & Exercise rights against sub-contractor or specialist. & $\mathrm{A}, \mathrm{B}, \mathrm{D}$ \\
\hline & & & RR22 & Set clear and mutually understood standard. & $\mathrm{A}, \mathrm{B}, \mathrm{D}$ \\
\hline & & & RR23 & Clear and open communication & $\mathrm{D}$ \\
\hline \multirow[t]{2}{*}{5} & R48 & Operational & RR24 & Tariff subsidy support by public. & A, B \\
\hline & & expectation & RR25 & Extending the project's concessionaire period & $\mathrm{B}$ \\
\hline 6 & & & RR30 & Performance bonds. & A, B \\
\hline \multirow[t]{6}{*}{7} & R42 & Late design change & RR31 & Practice change management. & A, D \\
\hline & & & RR32 & Appoint and work with professional consultant & $\mathrm{A}, \mathrm{B}, \mathrm{D}$ \\
\hline & & & RR33 & Develop good relation and communication with public party. & A, D \\
\hline & & & RR34 & Early changes. & $\mathrm{B}, \mathrm{D}$ \\
\hline & & & RR35 & Lock the drawing from any late changes that impact project cost and time. & $\mathrm{B}, \mathrm{C}, \mathrm{D}$ \\
\hline & & & RR36 & $\begin{array}{l}\text { Clause for entitlement to claim variation order if any additional cost } \\
\text { impact from changes. }\end{array}$ & $\mathrm{C}$ \\
\hline \multirow[t]{6}{*}{8} & R43 & Poor quality workmanship & RR37 & Appoint and work with competence specialist & $\mathrm{B}, \mathrm{C}$ \\
\hline & & & RR38 & Clear understanding of the project 's performance standard & $\mathrm{A}, \mathrm{B}, \mathrm{C}, \mathrm{D}$ \\
\hline & & & RR39 & Brief all project teams on the required standard to achieve. & $\mathrm{A}, \mathrm{D}$ \\
\hline & & & RR40 & To have a team to monitor and control the quality aspects on site & $\mathrm{B}, \mathrm{C}$ \\
\hline & & & RR41 & Relate payment mechanism to performance standard & A, D \\
\hline & & & RR42 & Retention sum & $\mathrm{A}, \mathrm{B}$ \\
\hline
\end{tabular}




\begin{tabular}{|c|c|c|c|c|c|}
\hline & & (Meso level -construction) & $\begin{array}{l}\text { RR44 } \\
\text { RR45 } \\
\text { RR46 }\end{array}$ & $\begin{array}{l}\text { Team to coordinate the work } \\
\text { Clear line of communication and reporting } \\
\text { Team building. }\end{array}$ & $\begin{array}{l}\text { C, D } \\
\text { A, B, C } \\
\text { C }\end{array}$ \\
\hline \multirow[t]{6}{*}{10} & R58 & Third party tort liability & RR74 & Consider the terms in the contract and all the detail & $\mathrm{B}, \mathrm{C}$ \\
\hline & & & RR75 & Provide and maintain a safe place of employment & $\mathrm{C}$ \\
\hline & & & RR76 & Implement all necessary procedure & $\mathrm{C}$ \\
\hline & & & RR77 & Provide training for employees & $\mathrm{A}, \mathrm{B}$ \\
\hline & & & RR78 & Comply to all local authority procedure & $\mathrm{A}, \mathrm{B}, \mathrm{C}$ \\
\hline & & & RR79 & Dedicated teams to monitor the compliance of statutory & $\mathrm{A}, \mathrm{B}, \mathrm{C}, \mathrm{D}$ \\
\hline \multirow[t]{3}{*}{11} & R36 & Design deficiency & RR47 & Team to coordinate the design & C, D \\
\hline & & & RR48 & Clear project's statement of need & $\mathrm{A}, \mathrm{B}, \mathrm{C}, \mathrm{D}$ \\
\hline & & & RR49 & Request of Information (RFI) application form & $\mathrm{C}, \mathrm{D}$ \\
\hline \multirow[t]{2}{*}{12} & R41 & Material / Labor availability & RR50 & Government support letter to import foreign worker & $\mathrm{A}, \mathrm{B}$ \\
\hline & & & RR51 & Government support letter to import controlled material & $\mathrm{A}, \mathrm{B}$ \\
\hline \multirow[t]{3}{*}{13} & R51 & Maintenance more frequently than & RR52 & Maintenance bonds from sub-contractor or specialist & $\mathrm{B}, \mathrm{C}$ \\
\hline & & expected & RR53 & Material used to comply the required standard & $\mathrm{C}$ \\
\hline & & & RR54 & To have a budget and team to conduct maintenance & $\mathrm{B}, \mathrm{C}$ \\
\hline \multirow[t]{4}{*}{14} & R50 & Maintenance cost higher & RR60 & Performance bond & $\mathrm{A}, \mathrm{B}$ \\
\hline & & & RR61 & Material used to comply the required standard & C, D \\
\hline & & & RR62 & To have a dedicated team & $\mathrm{A}, \mathrm{B}, \mathrm{C}, \mathrm{D}$ \\
\hline & & & RR63 & Maintenance schedule to be strictly complied & $\mathrm{A}, \mathrm{B}, \mathrm{C}$ \\
\hline \multirow[t]{5}{*}{15} & R37 & Unproven engineering technique & RR55 & Appoint and work with competence specialist & $\mathrm{C}, \mathrm{D}$ \\
\hline & & & RR56 & Requested performance bond from sub-contractor or specialist & $\mathrm{B}, \mathrm{C}$ \\
\hline & & & RR57 & Have a mutual understanding on the performance standard & $\mathrm{A}, \mathrm{B}, \mathrm{C}, \mathrm{D}$ \\
\hline & & & RR58 & Clear statement of need in the specification & $\mathrm{B}, \mathrm{D}$ \\
\hline & & & RR59 & To have a dedicated team to monitor and testing the works. & $\mathrm{C}, \mathrm{D}$ \\
\hline \multirow[t]{5}{*}{16} & $\mathrm{R} 49$ & Low operating productivity & RR55 & Appoint and work with competence specialist & $\mathrm{C}, \mathrm{D}$ \\
\hline & & & RR56 & Requested performance bond from sub-contractor or specialist & $\mathrm{B}, \mathrm{C}$ \\
\hline & & & RR57 & Have a mutual understanding on the performance standard & $\mathrm{A}, \mathrm{B}, \mathrm{C}, \mathrm{D}$ \\
\hline & & & RR58 & Clear statement of need in the specification & $\mathrm{B}, \mathrm{D}$ \\
\hline & & & RR59 & To have a dedicated team to monitor and testing the works. & $\mathrm{C}, \mathrm{D}$ \\
\hline \multirow[t]{3}{*}{17} & R6 & Poor financial market & RR1 & Raise funds from a number of sources. & $\mathrm{A}, \mathrm{B}$ \\
\hline & & & RR2 & Get government guarantee to the project's debt financiers & $\mathrm{A}, \mathrm{B}$ \\
\hline & & & RR3 & Get government to provide credit guaranteed finance. & A \\
\hline \multirow[t]{2}{*}{18} & $\mathrm{R} 8$ & Interest rate fluctuation & RR4 & Interest rate hedging tools - interest rate swap & $\mathrm{A}, \mathrm{B}$ \\
\hline & & & RR5 & Engaged lenders early in the bidding stage & A \\
\hline
\end{tabular}




\begin{tabular}{|c|c|c|c|c|c|}
\hline 19 & $\mathrm{R} 45$ & $\begin{array}{l}\text { Insolvency of sub-contractors or } \\
\text { supplier }\end{array}$ & $\begin{array}{l}\text { RR64 } \\
\text { RR65 } \\
\text { RR66 }\end{array}$ & $\begin{array}{l}\text { To have prevention and protection throughout the procurement selection } \\
\text { process. } \\
\text { To have awareness and planning during the delivery phase } \\
\text { To have recovery and impact mitigation plan }\end{array}$ & $\begin{array}{l}\text { A, B } \\
\text { A, B } \\
\text { A, B }\end{array}$ \\
\hline 20 & $\mathrm{R} 29$ & Level of demand for project & $\begin{array}{l}\text { RR67 } \\
\text { RR68 }\end{array}$ & $\begin{array}{l}\text { Guaranteed payment according to a minimum off take volume } \\
\text { Tariff re-negotiations with public party. }\end{array}$ & $\begin{array}{l}\text { A } \\
\text { A }\end{array}$ \\
\hline 21 & R25 & Geotechnical condition & $\begin{array}{l}\text { RR11 } \\
\text { RR12 } \\
\text { RR13 } \\
\text { RR14 }\end{array}$ & $\begin{array}{l}\text { Appoint and work with geotechnical specialist } \\
\text { Conduct a detail soil investigation } \\
\text { To have a rigorous testing procedures } \\
\text { To have a team to supervise and check the works }\end{array}$ & $\begin{array}{l}\text { B, C, D } \\
\text { C, D } \\
\text { C, D } \\
\text { C }\end{array}$ \\
\hline 22 & R14 & $\begin{array}{l}\begin{array}{l}\text { Fluctuation of material cost } \\
\text { (private) }\end{array} \\
\end{array}$ & RR10 & To have a long term supply contract with a supplier & $\mathrm{C}$ \\
\hline 23 & R12 & Market demand change & $\begin{array}{l}\text { RR6 } \\
\text { RR7 } \\
\text { RR8 } \\
\text { RR9 }\end{array}$ & $\begin{array}{l}\text { To have a realistic information from public about market. } \\
\text { To conduct internal market study } \\
\text { To get a guarantee payment according to a minimum off-take volume } \\
\text { To have a tariff re-negotiation to compensate for additional capital } \\
\text { investment. }\end{array}$ & $\begin{array}{l}\text { A } \\
\text { A, B } \\
\text { A, B } \\
\text { A, B }\end{array}$ \\
\hline
\end{tabular}




\section{REFERENCES}

Ahmad, E., Bhattacharya, A., Vinella, A., \& Xiao, K. (2014). Involving the Private Sector and PPPs in Financing Public Investments: Some opportunities and challenges.

Ahmed, A.B.K. (2007). A review of techniques for risk management in projects. EmeraldAn international journal, Vol, 14; Issue: 1; pp. 22-36.

Boadua, Y.F.A. (2012). An evaluation of risk factors impacting construction projects in Ghana. Journal of Engineering, Design and Technology, Vol. 10 Iss:3.

Baker, C.R. (2003). Investigating Enron as a public private partnership. Accounting, Auditing and Accountability Journal, 446466.

Bank Pembangunan Malaysia. P. (2011). Annual Report On Infrastructure. Malaysia: Bank Pembangunan Malaysia Berhad, 25-31.

Bing Li, A. A. (2000). VFM and risk allocation models in construction PPP projects. The Journal of Project Finance, 11-24.

Bing, L., Akintoye, A., Edwards, P. J., \& Hardcastle, C. (2005). The allocation of risk in PPP/PFI construction projects in the UK. International Journal of project management, 23(1), 25-35.

Boussabaine, A. (2014) Risk pricing strategies for public-private partnership projects. Wiley Blackwell, Oxford, UK.

Cervone, H. F. (2006). Project risk management. OCLC Systems and Services, 256-262.

Chan, C., Forwood, D., Roper H. and Sayers C. (2009). Public Infrastructure Financing: An International Perspective, Productivity Commission Staff Working Paper, Productivity Commission, Melbourne.

Chan, A.P.C. J.F. (2011). Empirical study of risk assessment and allocation of PPP projects in China. Journal of Management in Engineering @ ASCE, 136-148.

Chapman, C.B. and Ward, S.C. (1997) Project Risk Management: Processes, Techniques and Insights, Wiley, Chichester

Cheung, E.A.P. (2009). Reasons for implementing public private partnership projects: perspective from Hong Kong, Australian and British practitioners. Journal of property investment and finance, Vol 27 Iss: 1 pp 81-95.

Cheung, E.A.P. (2012). Factors contributing to successful public private partnership projects: Comparing Hong Kong with Australia and the United Kingdom. Journal of Facilities Management, Vol 10 Iss: 1 pp 45-58.

Chiu, T. a. (2010). Risk sharing in various PPP arrangements for the provision of water and wastewater services. Hong Kong: China Water Company.

CIDB (2014) Annual Report 2013, CIDB, Kuala Lumpur.

Creswell, John W. (2009). Research Design: Qualitative, Quantitative, and Mixed Methods Approaches. Edition. Los Angeles: Sage Publications, Inc.

Das, S.B. and James, C.R. (2013) Addressing Infrastructure Financing in Asia. Singapore APEC Study Centre Symposium on 'Building APEC and ASEAN Connectivity: Areas of Mutual Interest and Prospects of Cooperation', on 3rd April 2013 at Institute of Southeast Asian Studies (ISEAS), Singapore.

Department of Statistics Malaysia (2015). Gross Domestic Product Third Quarter 2014. Malaysia: Department of Statistics Malaysia.

Economic Planning Unit (EPU) (2015). Eleventh Malaysia Plan 2016-2020. Prime Minister Department, Federal Government Administrative Centre, Putrajaya, Malaysia.

Eldrup, A., \& Schütze, P. (2013). Organization and financing of public infrastructure projects. In A. Eldrup \& P. Schütze (Eds.), A path to economic growth and development of the Danish welfare model. Copenhagen: OFFENTLIGT-PRIVAT PARTNERSKAB

Faizul Azli Mohd Rahim, Nurshuhada Zainon, Saipol Bari Abd Karim, Akmal Latiff Ayob. (2017). Public-Private Partnership and Private Finance Initiative for Infrastructure Projects. University of Malaya Press.

Flanagan, R., \& Norman, G. (1997). Risk management and construction. Boston: Royal Institution of Chartered Surveyors.

Fuziah Abu Hanifah (2012) "Potential For Public-Private Partnership (PPP) for SDI in Malaysia”, Malaysian Centre for Geospatial Data Infrastructure, Ministry of Natural Resources and Environment.

Guideline to Victoria PPP (2000). Guideline to Victoria PPP. Melbourne: Victorian Department of Treasury and Finance (DTF).

Guthrie, L.M. (2003). Driving privately financed projects in Australia: what makes them tick. Accounting, Auditing and Accountability Journal, 493-511.

Hayes, R., Perry, J., \& Thompson, J. (1986). Risk management in engineering construction: A guide to project risk analysis and risk management London: Thomas Telford.

Hikmat, H.A. and Saba, F.N. (2009) Developing a green building assessment tool for developing countries-case of Jordan. Building and Environment; 44(5): 1053-64.

Hobbs, C.B. (2012). The paradox of risk management; a project management practice 
perspective. International Journal of Managing Projects in Business, 230-247.

Hodge, G.A. and Greve, C. (2007) "PublicPrivate Partnerships: An International Performance Review", Public Administration Review, 67(3): 545-558.

Ismail, I., Memon, A. H., \& Rahman, I. A. (2013). Expert opinion on risk level for factors affecting time and cost overrun along the project lifecycle in Malaysian construction projects. International Journal of Construction Technology and Management, 1(2), 22894454.

Karim, N. A. (2011). Risk allocation in PPP (PPP) project: A review on risk factors. International journal of sustainable construction engineering \& technology, 8-16.

Lewis, D. G. (2000). Evaluating the risks of PPPs for infrastructure projects. International Journal of Project Management, 108-118.

Mahamid, I. (2013). Common risks affecting time overrun in road construction projects in Palestine: Contractors' perspective. Australasian Journal of Construction Economics and Building, 13(2), 45-53.

Malaysian PPP Guideline (2009). Malaysian Public Private Partnership (PPP) Guideline. Putrajaya: Prime Minister Department.

Mateus, R., \& Bragança, L. (2011). Sustainability assessment and rating of buildings: Developing the methodology SBToolPTeH. Building and Environment, 46, 1962-1971.

Merna, T. \& Njiru, C. (2002) Financing infrastructure projects. Construction Management Series, $1^{\text {st }}$ ed. Thomas Telford Publishing

Ng, A. \& Loosemore M. (2005). Risk allocation in the private provision of public infrastructure. International Journal of Project Management, 1-11.

Ng, A. \& Loosemore, M. (2007). Risk Allocation in the private provision of public infrastructure. International Journal of Project Management, 25(1), 66-76.

OECD (Organisation for Economic Co-operation and Development) (2007), OECD Principles for Private Sector Participation in Infrastructure.

Pongsiri, N. (2002), Regulation and public private partnerships, The International Journal of Public Sector Management, Vol. 15 No. 6, pp. 487-95

Poole, Emily; Carl Toohey and Peter Harris (2014) Public Infrastructure: A Framework for Decision-making. Reserve bank of Australia.

Qing, S.W.M. F. (2004). Risk management framework for construction projects in developing countries. Construction
Management and Economics, Spon Press, pp.237-252.

Rahim, F.A., Muzaffar, S.A., Mohd Yusoff, N.S., Zainon, N. and Wang, C. (2014). Sustainable Construction through Life Cycle Costing. Journal of Building Performance, Volume 5 Issue 1

Singaravelloo, K. (2010). PPP: The right marriage between local government and the private sector in Malaysia? International Journal of Institutions and Economies, 2(2), 142-166.

Shen, L. Y., Platten, A., and Deng, X. P. (2006). "Role of public private partnerships to manage risks in public sector projects in Hong Kong." International Journal Project Management, 24(7), 587-594.

Takim, R.K.I. (2009). The Malaysian Private Finance Initiative and Value for Money. Asian Social Science, 103-111.

Tola, Amalia (2015). Public Private Partnership, an Effective Approach to Leverage the Quality of Public Goods and Services: The Case of Albania. Academic Journal of Interdisciplinary Studies. Vol. 4, No. 1.

UNESCAP. (2011). Guidebook on promoting good governance in PPP. New York and Geneva: United Nations, Geneva (Switzerland).

Wang, W. \& Dai, D. (2009) Risk Allocation Mechanism for Public-Private Partnership (PPP) Projects, IEEE.

World Bank (2012). Public-Private Reference Guide Version 1.0. Washington DC: International Bank for Reconstruction and Development/International, 33-37.

Zaini, A. A., Adnan, H., \& Haron, R. C. (2010). Contractors' Approaches to Risk Management at the construction Phase in Malaysia. Paper presented at the International Conference on Construction Project Management (ICCPM), Chengdu, China.

Zhang, X. (2005). Critical success factors for public-private partnerships in infrastructure development. Journal of construction engineering and management. 